\title{
Is the Pelješac Bridge Construction Going to Affect Tourism Sustainability of the Peninsula?
}

\begin{abstract}
The whole area of Dubrovnik-Neretva County, situated in the southeastern part of Croatia, is at the moment, in terms of road accessibility, still not satisfactorily connected with the rest of Croatia. The lack of its accessibility is mostly caused by the fact that Bosnia and Herzegovina's border line cuts in two the Dubrovnik-Neretva County's (land) territory. As a result, on the way from southwest to southeast, or from Split to Dubrovnik, one needs to cross the state border with Bosnia and Herzegovina twice. The construction of the Pelješac Bridge (together with a set of interconnecting roads) should improve the present situation significantly, mainly due to the expected redirection of most of the traffic to the new route across the Pelješac peninsula. However, it is fair to assume that this will additionally 'open' the entire Pelješac peninsula to the increased tourism related traffic, especially to the demand of one day visitors and/or weekend guests originating mostly from the nearby Bosnia and Herzegovina. Although the redirection of traffic is expected to create additional pressure on the peninsula's environment and its communal infrastructure, it seems that the Pelješac Bridge construction should not, only by itself, significantly jeopardize neither the sustainability, nor the (desirable) long-term market positioning of the peninsula on the tourism destination market.
\end{abstract}

Keywords: Pelješac Bridge, construction side-effects, tourism sustainability, Croatia

\section{Introduction}

The whole area of the Dubrovnik-Neretva County, situated in the southeastern part of Croatia, is at the moment, in terms of road accessibility, still not satisfactorily connected with the rest of Croatia. Apart from the lack in flow capacity of the existing road infrastructure, especially in the case of the main state road D-8 (Adriatic Highway), the lack of accessibility is mostly caused by the shape of Croatian territory i.e. the fact that Bosnia and Herzegovina's border line cuts in two not only the Dubrovnik-Neretva County's (land) territory, but also the Croatian (land) territory. As a result, on the way from southwest to southeast, or from Split to Dubrovnik, one needs to cross the state border with Bosnia and Herzegovina twice. Due to this major inconvenience, the appearance of annoying traffic jams is, at present, quite frequent, especially during the heavy tourism related traffic in summer months. The construction of the Pelješac Bridge (together with a set of interconnecting roads) should improve the present situation significantly, mostly due to the expected redirection of most of the traffic, to the new route across the Pelješac peninsula. The reason for this lies not only in the significant travel time reduction, but in the considerable improvement in traffic safety and comfort as well.

With the expected diversion of most of the ongoing traffic from its present route through Bosnia and Herzegovina to the new Peljašac Bridge route, it is fair to assume that a significant portion of the overall Pelješac road network will also encounter a notable increase in tourism related traffic, a large part of which will represent tourists in transit to Dubrovnik (and /or further to the southeast to Montenegro) and back. Assuming that a significant number of these tourists, while driving along the Pelješac roads, will recognize the natural beauty of the landscape as well as the leisure and/or recreational potential of the whole area, it is realistic to expect that some of them might decide to stay for some time, or return some other time. In any case, one should be

Ivo Kunst, PhD, Corresponding author, Institute for Tourism, Zagreb, Croatia; e-mail: ivo.kunst@iztzg.hr

Zoran Klarić, PhD, Institute for Tourism, Zagreb, Croatia; ORCID ID: https://orcid.org/0000-0003-3238-6668; e-mail: zoran.klaric@iztzg.hr

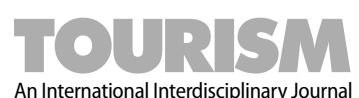


prepared for an increase in stationary tourist demand growth at least in some of the Pelješac settlements, and especially in those located in the vicinity of the Pelješac Bridge and the new interconnecting roads to be built.

The steady growth in stationary tourist demand over the long run, especially if it is substantial, might induce various interventions in the Pelješac municipalities' existing spatial plans. This might result in the establishment of a number of new tourism development zones and massive construction of new tourism accommodation facilities. Further, the construction of the new tourism related superstructure could represent too much of a burden for the relatively limited capacity of the peninsula's communal infrastructure.

Finally, it is fair to assume that the construction of the Pelješac Bridge, together with the interconnecting roads, will additionally 'open' the entire Pelješac peninsula to one day visitors and/or weekend guests, especially the ones originating from nearby Bosnia and Herzegovina. The growing dynamics of both of these market segments, mostly due to the additional pressure on scarce natural resources, might also affect the current market perception of the peninsula, as well as the sustainability of its long-term market positioning.

Summarizing the previous considerations, and understanding the sensitivity of the tourism sector to any change in the relevant socio-economic, ecological and/or political environment, this paper aims to investigate the extent to which, if any, the construction of the Pelješac Bridge might affect the locally preferred market positioning, as well as the long term tourism sustainability of the Pelješac peninsula.

Finally, although it is referring to various economic postulates, the paper is based primarily on the well-known theoretical concepts of 'tourist destination competitiveness' (Hassan, 2000; Ritchie \& Crouch, 2003; Heath, 2003; Dwyer \& Kim, 2003; Vanhove, 2005), 'sustainable development' (World Commission on Environment and Development [WCED], 1987; Butler, 1991; Sharpley, 2000; United Nations World Tourism Organisation [UNWTO], 2001), and 'carrying capacity' (Schneider, 1978; UNWTO, 1981; O'Reilly, 1987; United Nations Environmental Programme, Mediterranean Action Plan, Priority Actions Programme [UNEP / MAP / PAP], 1997).

\section{Setting the scene - Status quo analysis}

The Pelješac peninsula is a part of the Dubrovnik-Neretva County, Croatia's most south-eastern coastal County. Its land territory is cut in two by Bosnia and Herzegovina's the border line in the Neon municipality (Figure 1).

\section{Figure 1}

Location of the Dubrovnik-Neretva County, and Pelješac peninsula

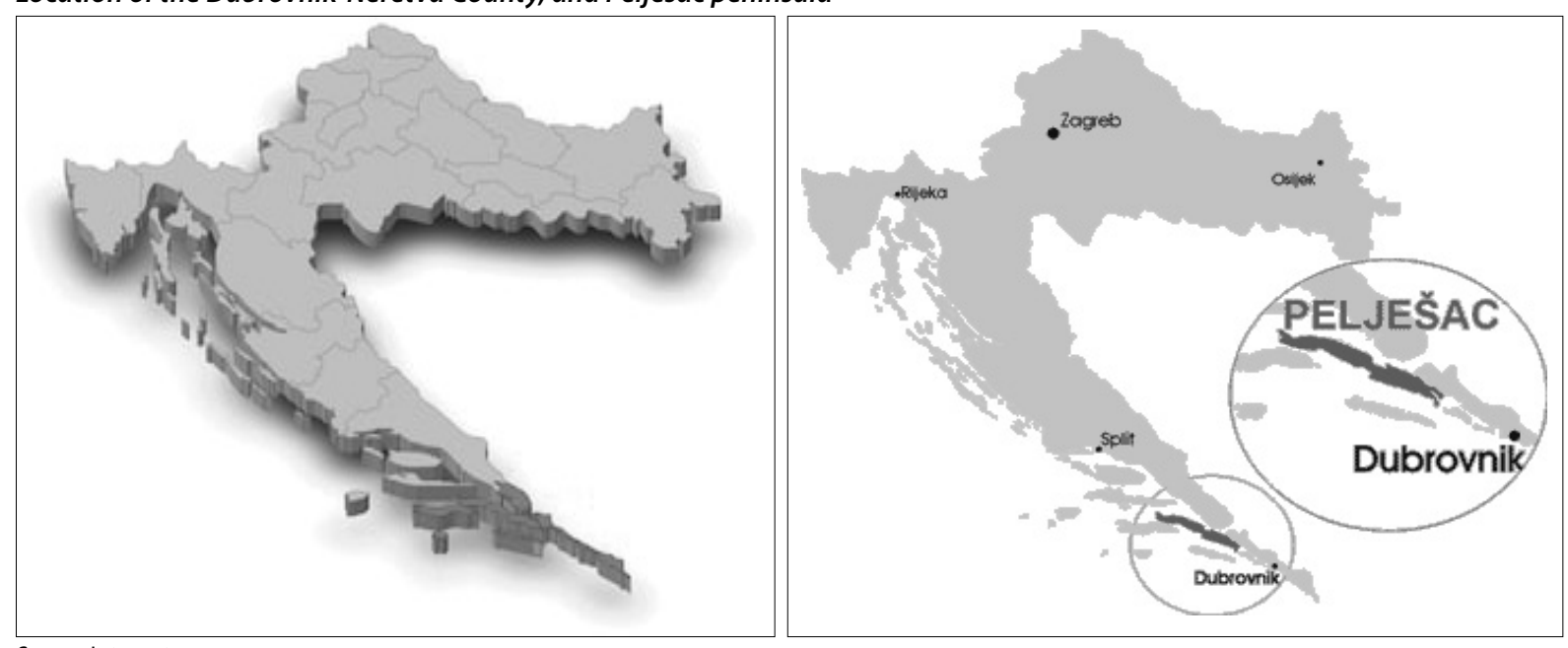

Source: Internet. 
In terms of its size (area), Pelješac is the second largest Croatian peninsula (after Istria). Due to its very narrow connection to the mainland, it has most of the characteristics of an island. From its junction with the mainland in Mali Ston to its most distant point, the cape of Lovište, it is $77 \mathrm{~km}$ long and covers an area of 348 $\mathrm{km}^{2}$. Among its other natural features, Pelješac in mostly known for its five, state-protected, nature areas, the most important of which are the Bay of Mali Ston, and the Little Sea (shellfish farming). In addition to the five state-protected nature areas, there are also eleven protected nature areas recorded within the Natura 2000 ecological network. Administratively, the Pelješac peninsula is divided into four municipalities - Orebić, Trpanj, Janjina, and Ston (Figure 2).

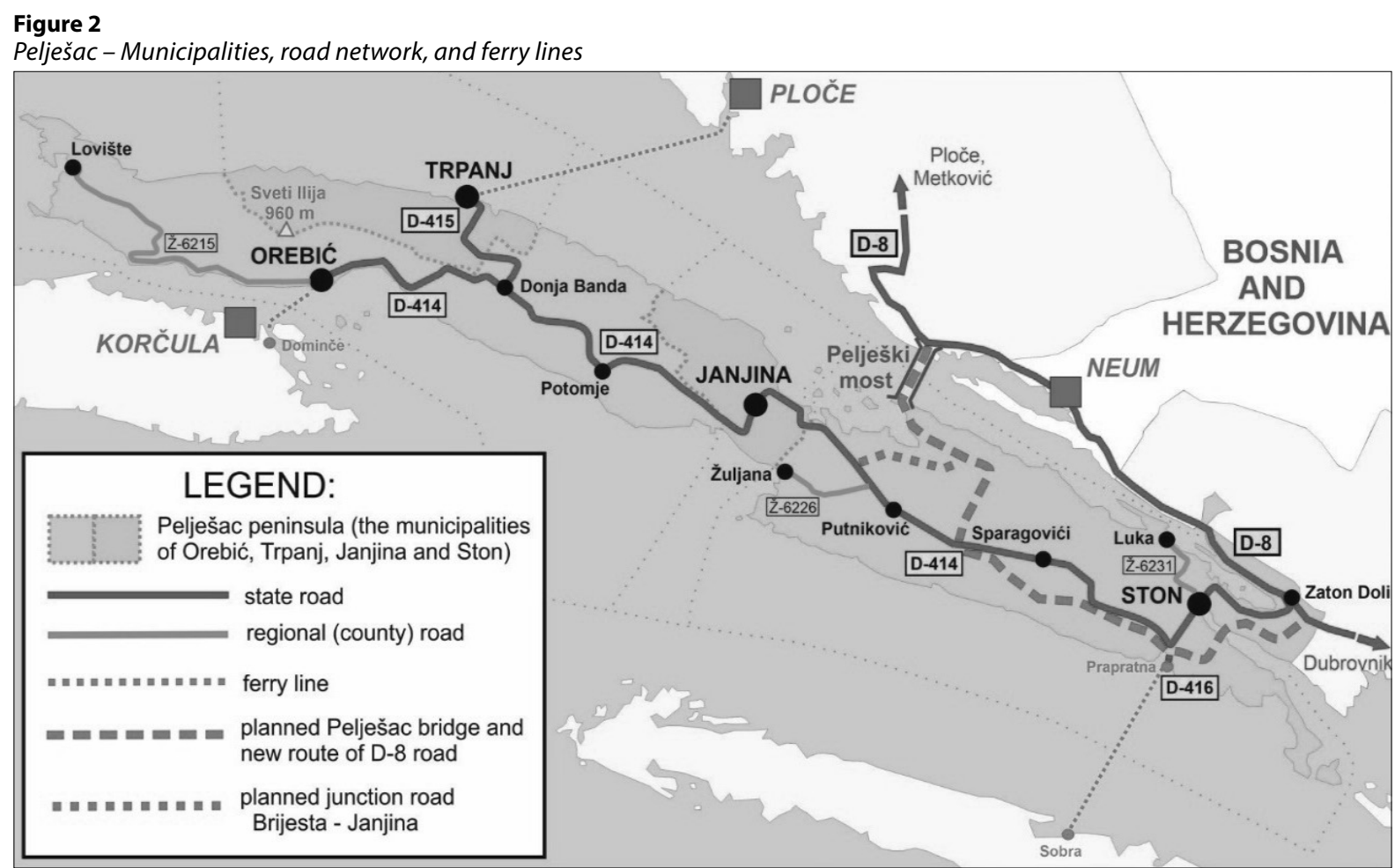

Source: Authors.

The Pelješac economy has, for centuries, been oriented to shipping and maritime transport (especially in Orebić), but also to shellfish farming (Ston and Janjina), salt production (Ston), and fishing (mostly in Orebić and Trpanj). Nevertheless, in the last thirty years, tourism, and agriculture, especially wine, and olive oil production have become the most important sectors of the peninsula's economy. One should also bear in mind that the Pelješac economy has, so far, been characterized by the non-existance of a single industrial plant.

When it comes to tourism development, in 2018, the whole Peljašac peninsula accounted for 167.5 thousand tourist arrivals, and for about 1.2 million tourist overnights (Central Bureau of Statistics of the Republic of Croatia, 2019). In comparison to the year 2010, overall tourist demand on the Pelješac peninsula has been increasing at an average rate of $6.2 \%$ per annum in terms of arrivals, or at an average rate of $5.6 \%$ per annum in terms of overnights. The growth dynamics in tourism demand reflected itself, more than evenly, on the availability of accommodation capacity. Specifically, in the 2010 to 2018 period, the number of accommodation units in all four Pelješac municipalities grew at an average rate of $9.6 \%$ per annum.

Notwithstanding the rapid growth dynamics of the overall accommodation capacity, its structure is still being characterized by a domination of tourist apartments within larger, family owned, households (65.7\%). At the 
same time, with the exception of the Orebic municipality, which is in tourism development terms, the most advanced Pelješac municipality, hotel accommodation is relatively under-represented in most of the Pelješac settlements. Mostly due to the prevalent structure of its accommodation capacity, the tourism in Pelješac has a pronounced seasonal character.

Regardless of the very favorable tourism development dynamics in recent years, the whole of Pelješac is characterized by generally unfavorable demographic trends. Namely, according to the latest 2011 census (Central Bureau of Statistics of the Republic of Croatia, 2012), the population of Pelješac has decreased by $5.3 \%$ compared to 2001 . The recorded rate of population decline between the two censuses is much more pronounced than the population decline rate at the level of Croatia as a whole $(-3.7 \%)$ and at the level of Dubrovnik-Neretva County (-1.0\%).

Mainly as a result of the on-going depopulation processes, the age structure of the population in all Pelješac municipalities is extremely unfavorable (Central Bureau of Statistics of the Republic of Croatia, 2012). Namely, the share of residents over the age of 64 amounts to a high of $23.2 \%$. This is significantly higher than the average of Croatia (16.7\%) and Dubrovnik-Neretva County (17.8\%). At the same time, the share of the Pelješac' population under the age of 15 (14.5\%) is much lower than the Croatian average (17.3\%) and that of the Dubrovnik-Neretva County average (16.3\%).

Finally, regarding the quality and/or availability of vital communal infrastructure, one could concur with the statement that both, electricity and water supply systems generally meet the existing needs of both, local population and the tourists. However, this cannot be said for the state of affairs in wastewater treatment, and solid waste management.

\section{Theoretical background - Literature review}

Under the influence of globally growing tourist demand, which has, prior to on-going corona virus pandemic, been expected to remain stable in the long run (UNWTO, 2019), the proliferation of an increasing number of attractive tourist destinations across the world, and the ever greater segmentation of tourist interests (Derrett, R., 2001; Gonzales \& Bello, 2002; Trauer, 2006; Pesonen 2012; Shi et al., 2018, Ernst \& Dolnicar, 2018), the tourist market in general is characterized more and more by a growing struggle to ensure the long-term interest/affinity of targeted demand segments (Kunst, 2017). As a result, the destination tourism policy must, more than ever, focus on a permanent improvement of its own competitive capability (Dwyer et al., 2009; Kunst, 2011; Estola \& Font, 2016; Algieri et al., 2018; Darwish \& Burns, 2019; Kim et al., 2019; Rašovská et al., 2021).

Since a tourist destination represents a clearly delineated geographic area which can be actively managed and in which a large number of co-producing actors offer a variety of tourist experiences (Buhalis, 2000; Haugland et al., 2011; Morisson, 2013; Mutuku, 2013), the tourism destination's competitiveness can be defined as "the ability to increase tourism expenditure, to increasingly attract visitors while providing them with satisfying, memorable experiences and to do so in a profitable way, while enhancing the well-being of destination residents and preserving the natural capital of the destination for future generations" (Ritchie \& Crouch, 2000; Ritchie \& Crouch, 2003; Dupeyras \& MacCallum, 2013). In this regard, further, the competitiveness of a tourist destination relies heavily upon the establishment of a suitable institutional framework, capable to monitor, control, and protect the resource basis of the destination (Goeldner et al., 2000).

Since a tourist destination competitiveness depends largely on the uniqueness, quality and/or preservation of its resource-attraction base, the problem of destination competitiveness management cannot be separated from the problem of destination sustainability (Pigram, 1990; Martin-Cejas \& Ramirez Sanchez, 2010; Sanagustin Fons et al., 2011; Moyle et al., 2014; Esparon et al., 2015; Aral-Tur \& Kozak, 2015; Cucculelli \&

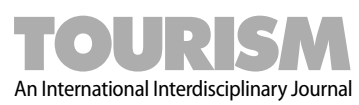

Zoran Klarić / Ivo Kunst

Pelješac Bridge Construction and Tourism Sustainability of the Peninsula, Croatia 
Goffi, 2016; Higgins-Desbiolles, 2018; Seguí-Amortegui et al., 2019; Guo et al., 2019; Font et al., 2021). Hence, the issue of destination sustainability has, for quite some time, been one of the central preoccupations of public authorities at national, as well as regional and/or local levels in almost all tourist destinations in the world (Inskeep, 1991; Butler, 1999; Dredge, 1999; Sharply, 2000; Sharpley, 2003; Mitchel \& Hall, 2005; Dredge, 2006; Whitford \& Ruhanen, 2010; Buckley, 2010; Butler, 2013; Ruhanen et al., 2015; Hall, 2016; Butzmann, 2017; Andersen et al., 2018).

The concept of destination sustainability is based on the idea that upon considering different development opportunities, one should necessarily take into account the need to "meet the needs of the present without compromising the ability of future generations to meet their own needs" (WCED, 1987). In other words, sustainable tourism development is a concept which advocates the idea that one should not adopt economic policies and / or practices that lead to an increase in the standard of living of current generations but which could, at the same time, permanently impoverish the destination's productive capacity, due to which future generations would be forced to face poorer development prospects and greater survival risks than is the case today (Liu et al., 2013). Hence, sustainable destination management implies that the tourism development process should be inter-generationally acceptable to all local community stakeholders since it would not change the environment in which it occurs to the extent that could, in any way, jeopardize the successful development and well-being of other activities and/or processes (Pearce et al., 1990; Butler, 1993). Finally, according to the UNWTO (2001), sustainable tourism development is envisaged as a practice "leading to management of all resources in such a way that economic, social and aesthetic needs can be fulfilled while maintaining cultural integrity, essential ecological processes, biological diversity and life support systems" (UNWTO, 2001). As a conclusion, sustainable tourism development simultaneously pays attention to both, the needs of tourists', and the need to safeguard the destinations' interests, thus, preserving equal development opportunities for the future.

Apart from the fact that the implementation of the sustainable (tourism) development concept in any particular region implies a lasting commitment of all development stakeholders to the principles of sustainability (Simmons, 1994; Joppe, 1996; Tosun, 2000; Bramwell \& Lane, 2000, Hall, 2011; Fodness, 2017; Guo et al., 2019), it should also be noted that the concept of sustainability is universally acceptable and applicable, regardless of the economic, socio-cultural and/or political specificities of any particular destination (Clarke, 1997; Tosun, 2000, 2001; Hardy et al., 2002; Swarbrooke \& Horner, 2004; Mitchell \& Hall 2005). Nevertheless, it is a concept whose implementation is specific to each destination (Cooper et al., 1998; Simon et al., 2004; Dinica, 2009; Guo et al., 2019), and should, therefore, be applied on a case-by-case basis (Manning, 1999).

The concept of long-term (destination) sustainability is closely related to the determination of the maximum acceptable level of tourist load within an area, a notion which is commonly known as a destination's carrying capacity (Carić \& Klarić, 2011; Liu \& Borthwick, 2011; Wei et al., 2015; Joshi \& Dahal, 2019). The carrying capacity of a tourist destination is usually defined as "the maximum number of people who can simultaneously visit a certain place without the adverse effect on the physical, economic and social environment, and without an unacceptable decline in visitor satisfaction" (UNWTO, 1981; McIntyre, 1993). Therefore, it can be said that the sustainable tourism development is nothing else but the development within the boundaries of a tourist destination's carrying capacity of (Carić \& Klarić, 2011).

Mostly due to the documented awareness about the negative socio-cultural effects of (excessive) tourism development (Smith, 1977; de Kadt, 1979; Marsiglio, 2016; Postma \& Schmuecker, 2017; Gravari-Barbas $\&$ Guinand, 2017), the contemporary approach to determining the carrying capacity of a tourist destination (region and / or area) is based on the equal treatment of several basic groups of indicators, mostly in the sphere of: (i) physical-ecological domain, (ii) socio-demographic domain and political-economic domain (Klarić et al., 2003).

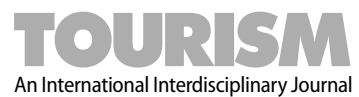

Zoran Klarić / Ivo Kunst

Pelješac Bridge Construction and Tourism Sustainability of the Peninsula, Croatia Vol. 69/ No. 2/ 2021/ 305 - 321 
As a result of gradual changes in the understanding of the complexities in a destination's carrying capacity assessment, all of the aforementioned indicator groups are nowadays being addressed with almost equal relevance. In other words, the primary orientation on the physical-ecological indicators has gradually been expanded so as to allow for the increasing awareness of the relevance of the socio-demographic, as well as the political-economic indicators (Carić \& Klarić, 2011; Sharma, 2016; Joshi \& Dahal, 2019; Ye et al., 2020).

Further, it should be stated that the relevance of socio-demographic and political-economic indicators should be of increasing importance, especially in the tourist destinations which are being characterized by significant inequalities in well-being, cultural beliefs and/or lifestyles among the domicile population and the tourists. The same should be valid in the case of destinations in which local government plays a key role in orchestrating the tourism development process (Severiades, 2000).

\section{Methodological approach}

Local residents should play a vital role in developing a desirable tourism model for each tourist destination (Muler Gonzalez et al., 2018) mostly since their goodwill is crucial to the success and sustainability of any tourism development (Bimonte $\&$ Punzo, 2016). Having this in mind, the methodological approach used in this paper was based on a two-stage process. The first stage was based on gathering concrete local stakeholders' viewpoints regarding not only the desirable direction of further tourism development on the Pelješac peninsula, but also the possible side-effects, positive or negative that the Pelješac Bridge construction might bring about, especially in relation the locally desired tourism development vision. Apart from the fact that local stakeholders should be most relevant in defining a particular destination's desirable tourism development path, the key argument for such a methodological approach lies in the presumption that a destination's vision can be effectively translated into reality only if the dominant stakeholder groups share similar attitudes on how the future should look like (Butler, 1980; Getz, 1992; Coccossis, 1996; Meetham 1998, Simpson, 2001; Ryan, 2002; Wehrmeyer et al., 2002; Reid et al., 2004; Van der Helm, 2009; Bimonte \& Punzo, 2016; Muler Gonzalez et al., 2018).

Based on the viewpoints that have been brought to notice during the stakeholder consultation process, the second stage of the process comprised of an expert assessment on how and to what extent the expected sideeffects of the Pelješac Bridge construction might affect the long-term sustainability of tourism development in each of the four Pelješac municipalities.

The stakeholder consultation process was conducted by means of semi-structured interviews with the selected representatives of different stakeholder groups, all with good understanding not only of the history of the Pelješac tourism development, but of its potential, direct and/or indirect socio-economic, spatial, ecologi$\mathrm{cal}$ and/or cultural side-effects as well. Each of the persons to be interviewed was contacted by the authors in advance in order to secure their cooperation, and to inform them in greater detail about the topics to be discussed. Further, in order to give them proper time to prepare, a prepared questionnaire was sent to each of the respondents a few days before the date of the interview. The interviewed persons included: (i) local politicians - municipal mayors (4), (ii) local tourism board directors (4), (iii) owners and/or managers of hotels, various types of family-owned accommodation facilities, well established food and beverage establishments, and travel agencies (16) as well as (iv) selected representatives of relevant local NGOs and / or leading civic organisations promoting 'green' development practices (11). Altogether, a total of 35 persons have been interviewed. Individual interviews, lasting for 60-90 minutes, were all held in Ston, Janjina, Orebić and Trpanj, the four municipal capitals. The entire research was conducted in May of 2018.

Individuals to be interviewed were, in part, predetermined in advance in order to ensure vital representation of local government and/or tourism board officials. The other persons to be interviewed were obtained using the snowball sampling method approach, an approach originally developed by Goodman (1961), which is 
quite often used in tourism related research (i.e. Stylianou-Lambert 2011; McLennan et al., 2014). Following the snowball sampling method approach, each preselected interviewee was asked to indicate a list of other prospective contact persons, and then the process was repeated.

All interviewees were asked to answer the questions grouped into four sets of interrelated topics, all in relation to the Pelješac Bridge construction, and its expected impact on tourism. The topics covered the following issues: (i) what type of tourism development would be mostly preferred by the local stakeholders, (ii) what are the key challenges related to tourism development that require immediate attention (regardless of the Bridge), (iii) are there going to be any foreseeable side-effects (on tourism) caused by the Pelješac Bridge construction (iv) is the Pelješac Bridge construction going to affect the peninsula's long run tourism sustainability. Interview topics were deliberately presented in as neutral a way as possible in order to invite interviewees to interpret issues in a way they considered most appropriate.

Following the completion of the stakeholder consultation process, and in order to assess, as objectively as possible, the long term sustainability of the Pelješac tourism development once the Pelješac Bridge will be fully operational, the second stage of the process focused on the analysis, as well as on the interpretation of the interviewees' viewpoints in order to relate them to the predetermined list of relevant tourism sustainability indicators. As advocated by eminent research (UNWTO, 2004; Choi \& Sirakaya, 2006; Hyde et al., 2007; Tanguay et al., 2013), for the purpose of this paper, particular attention has been given to eighteen tourism sustainability indicators grouped into five mutually inter-related areas (Table 1).

Table 1

Selected tourism sustainability indicators of interest for Peljašac peninsula

\begin{tabular}{|c|c|}
\hline $\begin{array}{l}\text { Spatial and } \\
\text { ecological } \\
\text { indicators }\end{array}$ & $\begin{array}{l}\text { - Beach capacity (square meters per user) } \\
\text { - Protected nature areas (do they exist, are they endangered by tourism) } \\
\text { - Construction level along the coastline (the percentage of coastline behind which } \\
\text { there is built-up area) }\end{array}$ \\
\hline $\begin{array}{l}\text { Communal } \\
\text { infrastructure } \\
\text { indicators }\end{array}$ & $\begin{array}{l}\text { - Electricity supply (percentage of households connected to the electricity supply network, } \\
\text { are there any restrictions) } \\
\text { - Water supply (percentage of households connected to the water supply network, } \\
\text { are there any shortages) } \\
\text { - Wastewater treatment (percentage of households connected to the sewerage network, } \\
\text { quality of wastewater treatment system) } \\
\text { - Solid waste management (share of waste separation, existence of waste treatment } \\
\text { plants where recycling is performed) }\end{array}$ \\
\hline $\begin{array}{l}\text { Traffic } \\
\text { infrastructure } \\
\text { indicators }\end{array}$ & $\begin{array}{l}\text { - Road traffic (quality of the local road network, are there any traffic jams) } \\
\text { - Parking (are there enough parking spaces in or near the main destinations) } \\
\text { - Maritime traffic (are there any ferry or boat connections, are there marinas or moorings, } \\
\text { intensity of nautical traffic) }\end{array}$ \\
\hline $\begin{array}{l}\text { Social } \\
\text { indicators }\end{array}$ & $\begin{array}{l}\text { - Age structure (percentage of young / elderly population) } \\
\text { - Educational structure (share of adult population with low / higher education) } \\
\text { - Population to tourist ratio (\# of local inhabitants / \# of tourists) } \\
\text { - Importance of tourism for local economy (\# of people who live of tourism) }\end{array}$ \\
\hline $\begin{array}{l}\text { Political \& } \\
\text { economic indicators } \\
\text { (based on surveys } \\
\text { and/or interviews) }\end{array}$ & $\begin{array}{l}\text { - Support of local population to tourism development (local viewpoints on tourism benefits) } \\
\text { - Political support for tourism development at the local/ regional level } \\
\text { - Construction of new accommodation capacities (whether significant growth of new rooms } \\
\text { and apartments can be expected) } \\
\text { - Real estate prices dynamics (whether a significant increase in property prices is expected) }\end{array}$ \\
\hline
\end{tabular}

Source: Authors.

Taking into account that the interviewed persons all represent highly educated and well trained professionals with relevant expertise for various qualitative assessments in the broad fields of both, tourism development and destination management, the used methodological approach has enabled a fairly objective detection of the key neuralgic areas in regard to the Pelješac Bridge construction that might be of concern for the future market positioning advocated by the locals and the overall tourism sustainability of the peninsula. 


\section{Local stakeholders' viewpoints - Results and discussion}

\subsection{What kind of tourism would be most desirable for the locals?}

Considering the desirable direction of the future tourism development, all interviewed persons, without exception, shared the opinion that tourism throughout the peninsula should continue to develop in accordance with the guidelines defined in the document entitled 'Pelješac tourism development strategy' (Institute for Tourism, 2011). This basically means that future tourism development should bring about a steady increase in the level of well-being of the locals, and affect the quality of their life in a most positive way. In that sense, therefore, the interviewees were almost unison in their view that '... the abundance of protected areas, as well as the characteristic features of the Pelješac landscape, especially its greenery...' are crucial for the long-term success on the tourism destination market. In this regard, it has especially been stressed that the degradation of '...the Pelješac image as a garden would represent an irreparable loss of the Pelješac core identity, as well as a huge blow to the spirit of place in most of the Pelješac settlements'. Therefore, the future development of tourism should by no means go in a direction that could, '... by means of excessive new construction, in any way degrade natural landscape, or the visual attractiveness of the settlements'.

Further, due to the small number of inhabitants, unfavorable demographic trends, and the high ecological sensitivity of the entire peninsula, tourism in Pelješac should continue to rely mainly '... on small family-based entrepreneurship, with small family-run (bed \& breakfast) accommodation facilities, (eco) campsites, and /or (boutique) hotels, dominating in the overall structure of the accommodation offer'. With this in mind, the interviewees strongly advocate the need to restrict the introduction of any new, tourism related, development zones, especially those intended for the construction of large scale tourism resorts. Instead, they are of the opinion that it is vital to encourage, as much as possible, '... the renovation/'touristification' of the already existing, old, stone build houses', where the utmost attention should be devoted to '... the local architectural tradition, quality of the materials, ambience and local flavor'. Only in this way will it be possible to avoid the '... unwanted syndrome of inflating the tourist bubble', and the danger of '... its bursting'.

Finally, most of the interviewees were of the opinion that '... although moderate growth in overnights is desirable and should continue in the future', such growth should always be kept '... within the sustainability limits of the communal infrastructure systems'. In any case, Pelješac should, by all means, strongly resist the possibility of an uncontrolled growth in tourism demand (and the emergence of so-called "overtourism").

\subsection{Key challenges to deal with (regardless of the Pelješac Bridge construction)}

Since practically all respondents share the view that tourism is '... the main driving force of the Pelješac economy ', and that it represents '... an activity without which Pelješac and its economy can no longer be imagined', it is only logical that they are also aware of a number of neuralgic points that, if disregarded, might become potential threats not only to the desired tourism development vision, but to the perceived image of Pelješac on the tourist destinations market. Namely, as most obvious neuralgic points in regard to future tourism development, the interviewees in particular emphasized:

(i) the diminishing usefulness of the main Pelješac road (D414), especially in the context of its throughput capacity ('impossible safe overtaking'), humps and/or holes ('poor surface rehabilitation'), and traffic safety ('moto cultivators on the road'),

(ii) inadequate wastewater drainage system, representing a potential threat to the cleanliness of the sea, especially in the context of the '...new hotel/resort construction in the tourism development zones in the Ston and Janjina municipalities', as well as

(iii) the still unresolved problems related to solid (and hazardous) waste management, mostly in the context of questionable completion deadline, and the proximity of the new Waste Management Center for the whole Dubrovnik-Neretva County to the naturally protected area of the Bay of Mali Ston.

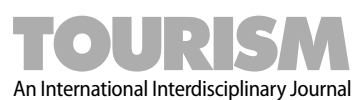


Apart from the above three challenges that need to be dealt with in order to safeguard the tourism attractiveness of the Pelješac peninsula, the majority of interviewees are increasingly aware that the demand growth, especially one day visitors and weekend guests, can dramatically exceed the available beach space in a relatively short time. Although the problem of beach load is still not perceived as a burning problem, especially since '...most of tourists are nowadays increasingly looking for swimming pools', the interviewees emphasized the need for increased investment in the beach space and beach infrastructure, partly to enlarge their carrying capacity, partly to improve their service offer and safety features, and partly to maintain high hygiene standards.

\subsection{Expected side effects of the Pelješac Bridge construction}

Anticipating the impact of the Pelješac Bridge construction, most of the interviewees do not consider the Bridge to be a major threat to the preferred tourism development vision. This is due to their belief that the increased transit will not significantly affect the number of stationary tourists in any of the Pelješac's settlements, at least in the short term. Nevertheless, the majority of respondents do agree that the construction of the Bridge will, to some extent, '... reflect itself on the growth dynamics in the number of overnights', but that this process will be '...split over a relatively long period' with '... no major impact in the short run'. This belief is primarily based on the assumption that only a relatively small, eastern, part of the peninsula, namely, the part along the Brijesta-Ston-Doli-Dubrovnik route, will face a significant increase in (tourist) transit, whereas the most of the settlements in the mid part, and to the west, especially in the Orebic and Trpanj municipalities, will still be relatively far from the Bridge, and thus not affected by the increased transit. In any case, the prevailing opinion is that the stationary tourist demand growth after the completion of the Bridge will follow, more or less, a very similar pattern '... as had been the case in the last ten years', that is prior to the Bridge construction. Also, the interviewees firmly believe that '...the expected (steady) growth in stationary demand' will be much more '.... result of the gradual improvement of the total destination offer, and the market recognition of the peninsula's product mix', and much less related to the improved accessibility of Peljašac itself. In other words, the vast majority of the interviewees are of the opinion that the growth of overnights in the years after the Bridge is fully operational will not be too invasive. Therefore, '.. providing the existing bottlenecks in communal infrastructure are accordingly dealt with', it is believed that it will be possible to keep the growth in stationary demand within the limits of sustainability.

Further, since the majority of the interviewees share the opinion that the construction of the Pelješac Bridge should not bring about a rapid increase in tourist overnights, it is not surprising that they also share the attitude that '...the existing accommodation facilities, with only minor upgrades and/or extensions', should be able to fully accommodate '...the additional number of newly induced stationary guests'. This is even more so if one takes into account the fact that the locals '... apart from the accommodation facilities in regular commercial use', also dispose of a '... relatively high number of fully refurbished houses/apartments' which are still not being used for tourist accommodation purposes. Finally, despite the fact that the construction of the Bridge may accelerate the need for some additional hotels and resorts, the locals are of the opinion, mostly due to their environmental awareness and the desire to preserve their present way of living, that '... collective accommodation facilities, especially big hotels and resorts, will never become the dominant type of accommodation on the peninsula'.

However, regardless of the pretty relaxed attitude concerning the growth dynamics of stationary tourism, the interviewees were almost unanimous in the view that the Pelješac Bridge construction will have a significant impact on the one-day visitors' and weekend demand, originating especially from the Neretva Delta area and from nearby municipalities in Bosnia and Herzegovina (corridor Vc from Mostar and / or Sarajevo). The reason for this lies in the significant shortening of travel time to most Pelješac beaches, as compared to travel time needed to reach the beaches of the Makarska Riviera which are, at present, of primary interest to the majority of the one day visitors from the mentioned areas. The expected significant increase in demand of one day visitors and weekend guests could, in the interviewees' opinion, especially in the short term, '... cause serious shortages in the overall beach space availability' throughout the peninsula. The beach space 
shortages might be especially severe in the Ston and Janjina municipalities, especially in the immediate vicinity of the Bridge. Nevertheless, due to the long (still unused) coastline on which new beaches can be created, the potential shortages of beach space can, if need be, '... overcome in a relatively short time'.

\subsection{Pelješac Bridge construction and the long-term tourism sustainability of the peninsula}

Since the Bridge is still under construction and will not be open to traffic until spring of 2022, precise data needed for the calculation of most of the individual sustainability indicators are still not available. As a result, in assessing the expected impact of most of the indicators on the peninsula's tourism sustainability, one had to rely mostly on the respondents' attitudes and their interpretation.

Notwithstanding the fact that the interviewees, predominantly do not consider the Bridge to be a major threat to the locally preferred tourism development vision, most of them are, nevertheless, aware that it could affect the peninsula's long term market position as well as its sustainability (Table 2).

Table 2

Expected effects of the Pelješac Bridge on the selected tourism sustainability indicators

\begin{tabular}{|c|c|c|c|c|c|}
\hline $\begin{array}{l}\text { Indicator } \\
\text { Group }\end{array}$ & Indicator & Orebić & Trpanj & Janjina & Ston \\
\hline $\begin{array}{l}\text { Spacel \& } \\
\text { ecology } \\
\text { related }\end{array}$ & $\begin{array}{l}\text { - Beach capacity } \\
\text { - Protected nature areas } \\
\text { - Construction level along the coastline }\end{array}$ & $\begin{array}{l}\check{\theta} \\
\ddot{\ominus}\end{array}$ & $\begin{array}{l}\bigodot \\
\bigodot \\
\bigodot\end{array}$ & $\begin{array}{l}\check{\ddots} \\
\check{\theta}\end{array}$ & $\begin{array}{l}\check{\theta} \\
\check{\theta}\end{array}$ \\
\hline $\begin{array}{l}\text { Communal } \\
\text { infrastructure } \\
\text { related }\end{array}$ & $\begin{array}{l}\text { - Electricity supply } \\
\text { - Water supply } \\
\text { - Wastewater treatment } \\
\text { - Solid waste treatmenty }\end{array}$ & 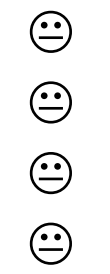 & 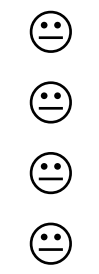 & $\begin{array}{l}\stackrel{\ominus}{\ominus} \\
\check{\bullet} \\
\check{\sigma}\end{array}$ & $\begin{array}{l}\ddot{\theta} \\
\ddot{\circ} \\
\check{\sigma}\end{array}$ \\
\hline $\begin{array}{l}\text { Traffic } \\
\text { related }\end{array}$ & $\begin{array}{l}\text { - Road traffic } \\
\text { - Parking s } \\
\text { - Maritime traffic }\end{array}$ & $\begin{array}{l}\check{\sigma} \\
\check{\ominus} \\
\check{\bullet}\end{array}$ & $\begin{array}{l}\ddot{\bullet} \\
\ddot{\bullet}\end{array}$ & $\begin{array}{l}\ddot{\theta} \\
\ddot{\theta}\end{array}$ & 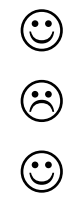 \\
\hline $\begin{array}{l}\text { Socially } \\
\text { related }\end{array}$ & $\begin{array}{l}\text { - Age structure } \\
\text { - Educational structure } \\
\text { - Population to tourist ratio } \\
\text { - Importance of tourism for local economy }\end{array}$ & 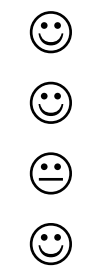 & 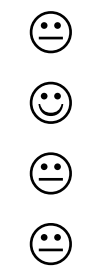 & 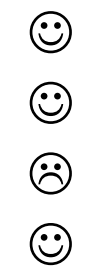 & $\begin{array}{l}\bullet \\
\bullet \\
\bullet\end{array}$ \\
\hline $\begin{array}{l}\text { Politically \& } \\
\text { economically } \\
\text { related }\end{array}$ & $\begin{array}{l}\text { - Support of local population to tourism development } \\
\text { - Political support for tourism development at the local/ regional level } \\
\text { - Construction of new accommodation capacities } \\
\text { - Real estate prices dynamics }\end{array}$ & 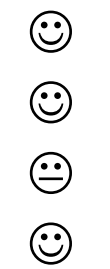 & 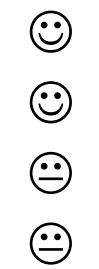 & 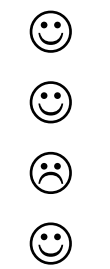 & 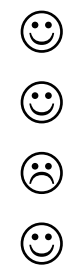 \\
\hline
\end{tabular}

$\bigodot_{\text {should not have a negative impact; }} \bigodot_{\text {should be neutral; }} \bigodot_{\text {might have a negative impact. }}$

Source: Authors, based on the stakeholders' attitudes, opinions, and viewpoints. 
Starting with the spatial-ecological sustainability indicators, almost all respondents share the opinion that the expected increase of (tourist) transit could, '... but only to a lesser extent', reflect itself on the current level of construction activity along the peninsula's coastal belt, mainly through investment projects in the already existing tourist development zones in Janjina and Ston municipalities. However, this should have no adverse implications on '...the cleanliness of the sea and the protection of the nearby natural heritage locations'. The same conclusion should hold in the case of the increased demand for beach space usage.

The reasons for such an assessment are based predominantly on the provisions of current spatial plans (the municipal and the County level) which require that each new collective accommodation facility to be built in this area must dispose of its own fully operational (contemporary) wastewater treatment system. Further, since '... there are no major pollutants neither on the peninsula, nor in the surrounding area', it is fair to conclude that the sea water quality in the environmentally protected nature areas of Bay of Mali Ston and the Little Sea, should remain at a very high level, especially since '... additional protection measures are constantly being introduced in order to prevent even a slightest possibility of shell farming endangerment'. The Pelješac Bridge construction, and the expected increase in tourist transit cannot, as voiced be the interviewees, jeopardize these activities in any significant way whatsoever.

The only real danger to the deterioration of the spatial and ecological sustainability indicators, which could be indirectly connected to the Pelješac Bridge construction, relates to the potential threat of the '... (uncontrolled) increase in newly built family-owned apartments and holiday homes' in the Ston and Janjina municipalities.

In terms of communal infrastructure, an having in mind the already existing deficiencies mostly in the area of the wastewater/drainage treatment, and solid waste disposal, the Pelješac Bridge construction, according to the respondents, should not '...significantly deepen the already existing communal problems'. Nevertheless, an increase in number of persons in transit implies the increase in the food/beverage consumption along the route, resulting in a larger quantity of solid waste to be removed. This might especially be true in the case of Janjina and Ston municipalities. However, most of the interviewees have addressed this more as a theoretical rather than a practical problem.

On the other hand, and concerning the traffic infrastructure sustainability indicators, the respondents fully share the view that the Pelješac Bridge construction, and the necessary junction roads, will '....significantly improve the current traffic situation in the Ston municipality', mainly due to the switch of most of the transit from the existing state road D-414 to the new Pelješac motorway. Nevertheless, bearing in mind that, at least for the time being, the new Pelješac motorway will be limited only to the eastern part of the peninsula (connecting Ston with Dubrovnik), the respondents indicated that the expected increase in one day visitors' and weekend demand will have '... a negative impact on the already insufficient throughput, as well as safety' along the D414 - the main traffic corridor on route to Orebić and Trpanj municipalities in the west. Likewise, while most of the respondents believe that the present lack of parking spaces, especially evident in the summer months, '...should still not be considered as a serious problem', it is expected that the Bridge construction will significantly '...inflame the issue'. The problem might occur especially '... in the vicinity of some of the most attractive beaches' of central Pelješac. Finally, the interviewees have expressed concern that the Bridge construction might lead to a significant reduction in sea bound traffic on the existing Trpanj-Ploče ferry line, which could endanger its present cost-effectiveness. Given that '.... large number of Trpanj residents, and to some extent Orebić residents', use this ferry line on a regular basis either '...for acquiring education, and health care related services, or for shopping', its possible termination would represent an irreparable damage to the local community, and would greatly diminish the quality of life of a relatively large number of people in these two municipalities.

With reference to the socio-demographic sustainability indicators, and having in mind the present unfavorable situation, most of the respondents, shyly indicated the possibility '...of gradual positive changes' in the period after the Bridge completion, especially in the medium and long term. This refers mostly to the possible 
improvement in the population's age and/or educational structure. Namely, since all Pelješac municipalities are currently being characterized by negative demographic trends due to a continuing outflow of young, highly educated persons, the completion of Pelješac Bridge might '...generate new jobs and new small start-ups' not only in the tourism sector, but in tourism complementary sectors as well. Such a trend could gradually reverse the negative migratory balance, not only by reducing the outflow of young, well-educated persons from Pelješac, but also by attracting people of the same demographic characteristics from nearby areas on the coast/continent. On the other hand, despite the fact that the Pelješac Bridge construction should not significantly affect the current economic structure of the peninsula, the respondents pointed out the possibility of '... a further deterioration in the number of tourists to local population ratio', especially if the current demographic trends do not change for the better.

Finally, and addressing the political and economic sustainability indicators, all the respondents have, without exemption, indicated the Pelješac Bridge construction will have '... no impact whatsoever on the local population's views on tourism (and its positive effects on the standard of their living), nor on the '...present degree of their political support' to further tourism development. Specifically, regardless of the expected increase in demand for (relatively limited) beach space, it is expected that the increased volume of (tourist) transit will over time have a positive effect on the '... occupancy rates and price level in all accommodation types'. It is also generally believed that the construction of the Pelješac Bridge will '...positively affect real estate, and property prices', which should also be beneficial for most of the local residents. Finally, any increase in the '... already high real estate prices' should represent a serious barrier to excessive growth of demand for new housing and tourism accommodation facilities by people who do not permanently reside on the peninsula, although '...this demand cannot be completely ruled out'.

\section{Concluding remarks}

Tourism activity on the Pelješac peninsula has been stable and growing steadily over the last ten years in a sustainable way. Despite the fact that such an outcome has a lot to do with the long-term favorable trends in the global tourism market (World Economic Forum [WEF], 2019), it is also, largely, a result of the quality of the peninsula's attraction base, the chosen direction/model of its tourism development, as well as the authenticity of its market positioning. It is also worth noting that the whole Pelješac peninsula has, so far, been able to successfully resist most of the pitfalls related to overtourism.

The construction of the Pelješac Bridge could alter the present situation somewhat. Namely, although the Bridge represents one of the most important projects in the Croatian transport infrastructure, its construction will, without doubt, considerably shift the current traffic flows from their present route, resulting in a significant increase not only in local daily migrations, but in the much increased tourism and goods transportation related transit as well.

In order to determine to what extent should the Pelješac Bridge construction be considered a potential threat not only to the desired local vision of the peninsula's tourism development, but also to its long run market sustainability, the viewpoints of relevant local stakeholders, equally distributed across each of the four Pelješac municipalities have been collected, analyzed, and interpreted.

Summarizing the views of the interviewees, and despite the expected deterioration of some of the selected indicators of tourism sustainability, it can be concluded that the Pelješac Bridge construction should bring about more benefits than harm to each of the four municipalities. In other words, it seems that the Pelješac Bridge construction should not, only by itself, significantly jeopardize the (desirable) long-term market positioning of the peninsula as a whole or each and every of the four Pelješac municipalities on the tourism market. This should especially be the case if each of the four municipalities managed the tourism development process within their territorial limits systematically, in line with the vested interests of the relevant local stakeholder groups, and in mutual coordination. 
On the other hand, however, and regardless of the Bridge construction, the analysis confirmed that the future tourism development of the Pelješac peninsula, as well as its currently perceived market image will be somewhat compromised over the long run if several neuralgic points in the sphere of communal and transport infrastructure, as detected by the interviewees, are not systematically dealt with and gradually eliminated.

In any case, to manage the tourism development process in an effective way, the local (tourism) authorities in each of the four municipalities should closely monitor the situation year in and year out, and, if need be, undertake remedial action.

\section{References}

Algieri, B., Aquino, A., \& Socorro, M. (2018). International competitive advantages in tourism: An eclectic view. Tourism Management Perspectives, 25, 41-52.

Andersen, I.M.V., Blichfeldt, B.S., \& Liburd, J.J. (2018). Sustainability in coastal tourism development: An example from Denmark. Current Issues in Tourism, 21, 1329-1336.

Aral-Tur, A., \& Kozak, M. (2015). Introduction. In A. Aral-Tur \& M. Kozak (Eds.), Destination competitiveness, the environment and sustainability: Challenges and cases. CABI.

Bimonte, S., \& Punzo, L.F. (2016), Tourist development and host-guest interaction: An economic exchange theory. Annals of Tourism Research, 58, 128-139.

Buckley, R. (2012). Sustainable tourism: Research and reality. Annals of Tourism Research, 39, 528-546.

Buhalis, D. (2000). Marketing the competitive destination of the future. Tourism Management, 21, 97-116

Butler, R. (2013). Sustainable tourism - The undefinable and unachievable pursued by the unrealistic. Tourism Recreation Research, 38(2), 221-226.

Butler, R. W. (1993). Tourism - An evolutionary perspective. In J.G. Nelson, R. Butler, \& G. Wall (Eds.), Tourism and sustainable development: Monitoring, planning, and managing (pp. 26-43). Heritage Resource Centre, University of Waterloo.

Butler, R.W. (1980). The concept of a tourist area cycle of evolution: Implications for management of resources. Canadian Geographer, 24(1), 5-12.

Butler, R.W. (1991). Tourism, environment and sustainable development. Environmental Conservation, 18(3), $201-209$.

Butler, R.W. (1999). Sustainable tourism: A state-of-the-art review. Tourism Geographies, 1(1), 7-25.

Butzmann, E., \& Job. H. (2017). Developing a typology of sustainable protected area products. Journal of Sustainable Tourism, 25, 1736-1755.

Carić, H., \& Klarić, Z. (2011). Istraživanja prihvatnog kapaciteta - Međunarodna i hrvatska iskustva [Carrying capacity research - International and Croatian experiences]. In S. Čorak (Ed.), Izazovi upravljanja turizmom (pp. 107-121). Institute for Tourism.

Central Bureau of Statistics of the Republic of Croatia. (2012). Promet turista u primorskim gradovima i općinama 2012 [Tourism in seaside towns and municipalities 2012]. Central Bureau of Statistic of the Republic of Croatia.

Central Bureau of Statistics of the Republic of Croatia. (2019). Promet turista u primorskim gradovima i općinama 2019 [Tourism in seaside towns and municipalities 2019]. Central Bureau of Statistic ofthe Republic of Croatia.

Choi, H.C., \& Sirakaya, E. (2006). Sustainability indicators for managing community tourism. Tourism Management, 27, 1274-1289.

Clarke, J. (1997). A framework of approaches to sustainable tourism. Journal of Sustainable Tourism, 5(3), $224-233$.

Coccossis, H. (1996). Tourism and sustainability: Perspectives and implementation. In G.K. Priestley, J.A. Edwards, \& H. Coccossis (Eds.), Sustainable tourism: European perspectives. CAB International.

Cooper, C., Fletcher, J., Gilbert, D., Shepherd, R., \& Wanhill, S. (1998). Tourism principles and practice (2nd ed.). Longman.

Cucculelli, M., \& Goffi, G. (2016). Does sustainability enhance tourism destination competitiveness? Evidence from Italian destinations of excellence. Journal of Cleaner Production, 111(B), 370-382.

Darwish, A., \& Burns, P. (2019). Tourist destination reputation: An empirical definition. Tourism Recreation Research, 44(2), 153-162.

de Kadt, E. (1979). Social planning for tourism in the developing countries. Annals of Tourism Research, 6, 36-48. 
Derrett, R. (2001). Special interest tourism: Starting with the individual. In N. Douglas, N. Douglas, \& R. Derret (Eds.), Special interest tourism (pp. 1-28). Wiley.

Dinica, V. (2009). Governance for sustainable tourism: A comparison of international and Dutch visions. Journal of SustainableTourism, 17, 583-603.

Dredge, D. (1999). Destination place planning and design. Annals of Tourism Research, 26(4), 772-791.

Dredge, D. (2006). Policy networks and the local organization of tourism. Tourism Management, 27, 269-280.

Dupeyras, A., \& MacCallum, N. (2013). Indicators for measuring competitiveness in tourism: A guidance document. OECD Tourism Papers, 2013/02. OECD Publishing.

Dwyer, L., \& Kim, C. (2003). Destination competitiveness: Determinants and indicators. Current Issues in Tourism, 6(5), 369-414.

Dwyer, L., Edwards, D., Mistilis, N., Roman, C., \& Scott, N. (2009). Destination and enterprise management for a tourism future. Tourism Management, 30, 63-74.

Ernst, D., \& Dolnicar, S. (2018). How to avoid random market segmentation solutions. Journal of Travel Research, $57(1), 69-82$.

Esparon, M., Farr, M., Stoeckl, N., \& Larson, S (2015). The significance of environmental values for destination competitiveness and sustainable tourism strategy making: Insights from Australia's Great Barrier Reef World Heritage area. Journal of Sustainable Tourism, 23(5), 706-725.

Estola, J., \& Font, X. (2016). European tourism policy: Its evolution and structure. Tourism Management, 52, 230-241.

Fodness, D. (2017). The problematic nature of sustainable tourism: Some implications for planners and managers. Current Issues in Tourism, 20, 1671-1683.

Font, X., Torres-Delgado, A., Crabolu, G., Palomo Martinez, J., Kantenbacher, J., \& Miller, G. (2021). The impact of sustainable tourism indicators on destination competitiveness: The European Tourism Indicator System. Journal of Sustainable Tourism. https://doi.org/10.1080/09669582.2021.1910281

Getz, D. (1992). Tourism planning and destination lifecycle. Annals of Tourism Research, 19(4), 752-770.

Goeldner, R., Ritchie, J., \& McIntosh, R. (2000). Tourism: Principles, practices, philosophies (8th ed.). John Wiley \& Sons.

Gonzalez, A.M., \& Bello, L. (2002). The construct "lifestyle" in market segmentation: The behaviour of tourist consumers. European Journal of Marketing, 36(1/2), 51-85.

Goodman, L.A. (1961). Snowball sampling. Annals of Mathematical Statistics, 32(1), 148-170.

Gravari-Barbas, M., \& Guinand, S. (2017). Tourism and gentrification in contemporary metropolises: International perspectives. Routledge.

Guo, Y., Jiang, J., \& Li, S. (2019). A sustainable tourism policy research review. Sustainability, 11, Article 3187.

Hall, C.M. (2011). Policy learning and policy failure in sustainable tourism governance: From first and second-order to third-order change? Journal of Sustainable Tourism, 19, 649-671.

Hall, C.M. (2016). Intervening in academic interventions: Framing social marketing's potential for successful sustainable tourism behavioral change. Journal of Sustainable Tourism, 24, 350-375.

Hardy, A., Beeton, R.J.S., \& Pearson, L (2002). Sustainable tourism: An overview of the concept and its position in relation to conceptualizations of tourism. Journal of Sustainable Tourism, 10(6), 476-496.

Hassan, S. (2000). Determinants of market competitiveness in an environmentally sustainable tourism industry. Journal of Travel Research, 38(3), 239-245.

Haugland, S.A., Ness, H., Gronseth, B.O., \& Aarstad, J. (2011). Development of tourism destinations: An integrated multilevel perspective. Annals of Tourism Research, 38(1), 268-290.

Heath, E. (2003). Towards a model to enhance destination competitiveness: A South African perspective. Journal of Hospitality and Tourism Management, 10(2), 124-141.

Higgins-Desbiolles, F. (2018). Sustainable tourism: Sustaining tourism or something more? Tourism Management Perspectives, 25, 157-160.

Hyde, R., Moore, R., Kavanagh, L., Schianetz, K., Prasad, D., Blair, J., Watt, M., Bayada, B., \& Hair, A. (2007). Planning and design standard for improving sustainability of neighborhoods and precincts. CRC for Sustainable Tourism.

Inskeep, B. (1991). Tourism planning: An integrated and sustainable development approach. Van Nostrand Reinhold.

Institute for Tourism. (2011). Plan razvoja turizma Pelješca [Peljesac tourism development plan].

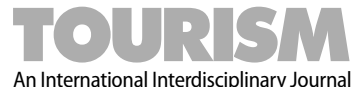

Zoran Klarić / Ivo Kunst

Pelješac Bridge Construction and Tourism Sustainability of the Peninsula, Croatia 
Joppe, M. (1996). Sustainable tourism community development revisited. Tourism Management, 17(7), 475-479.

Joshi, S., \& Dahal, R. (2019). Relationship between social carrying capacity and tourism carrying capacity: A case of Annapurna Conservation Area, Nepal. Journal of Tourism \& Hospitality Education, 9, 9-29.

Kim, H., Joun, H.J., Choe, Y., \& Schroeder, A. (2019). How can a destination better manage its offering to visitors? Observing visitor experiences via online reviews. Sustainability, 11(17), Article 4660.

Klaric, Z., Mangion, M.I., Satta, A., \& Travis, A.S. (2003). Guide to good practice in tourism carrying capacity assessment. UNEP/ MAP/RAC-PAP.

Kunst, I. (2011). Upravljanje turističkom destinacijom u Hrvatskoj - Ograničenja i mogućnosti [Tourist destination management in Croatia - Limitations and possibilities]. In S. Čorak (Ed.), Izazovi upravljanja turizmom (pp. 1-14). Institute for Tourism.

Kunst, I. (2017). Image redesign as a tool for safeguarding a destination's market prosperity: The case of Dubrovnik. Sociology and Space, 55(1), 55-75.

Liu, C. H., Tzeng, G.H., Lee, M.H., \& Lee, P.Y. (2013). Improving metro-airport connection service for tourism development: Using hybrid MCDM models. Tourism Management Perspectives, 6, 95-107.

Liu, R.Z., \& Borthwick, A.G.L. (2011). Measurement and assessment of carrying capacity of the environment in Ningbo, China. Journal of Environmental Management, 92, 2047-2053.

Manning, T. (1999). Indicators of tourism sustainability. Tourism Management, 20(1), 3-6.

Marsiglio, S. (2016). Uncertainty, crowding aversion and tourism aversion in tourism destinations. Tourism Economics, 22(1), 111-123.

Martin Cejas, R.R., \& Ramirez Sanchez, P.P. (2010). Ecological footprint analysis of road transport related to tourism activity: The case of Lanzarote Island. Tourism Management, 31, 98-103.

McIntyre, G. (1993). Sustainable tourism development: Guide for local planners. United Nations World Tourism Organization.

McLennan, C.J., Ritchie, B.W., Ruhanen, L.M., \& Moyle, B.D. (2014). An institutional assessment of three local governmentlevel tourism destinations at different stages of the transformation process. Tourism Management, 41, $107-118$.

Meethan, K. (1998). New tourism for old? Policy developments in Cornwall and Devon. Tourism Management, 19(6), 583593.

Mitchell, M., \& Hall, D. (2005). Rural tourism as sustain-able business: Key themes and issues. In D. Hall, I. Kirkpatrick, \& M. Mitchell (Eds.), Rural tourism and sustainable business (pp. 3-16). Channel View Publications

Morisson, A.M. (2013). Marketing and managing tourist destinations. Routledge.

Moyle, B.D., McLennan, C.L.J., Ruhanen, L., \& Weiler, B. (2014). Tracking the concept of sustainability in Australian tourism policy and planning documents. Journal of Sustainable Tourism, 22, 1037-1051.

Muler Gonzalez, V., Coromina, I., \& Gali, N. (2018). Overtourism: Residents'perceptions of tourism impact as an indicator of residentsocial carrying capacity - Case study of a Spanish heritage town. Tourism Review, 73(3), 277-296.

Mutuku, C. (2013). Tourism destinations. Definitions, changes and trends. GRIN Verlag. https://www.grin.com/ document/381273

O'Reilly A.M. (1986). Tourism carrying capacity. Concepts and issues. Tourism Management, 7(3), 254-258.

Pearce, D, Barbier, E., \& Marakandya, A. (1990). Sustainable development, economics and environment in the Third World. Edward Elgar Publishing.

Pesonen, J.A. (2012). Segmentation of rural tourists: Combining push and pull motivations. Tourism and Hospitality Management, 18(1), 69-82

Pigram, J.J. (1990). Sustainable tourism - Policy considerations. The Journal of Tourism Studies, 1, 2-8.

Postma, A., \& Schmuecker, D. (2017). Understanding and overcoming negative impacts of tourism in city destinations: Conceptual model and strategic framework. Journal of Tourism Futures, 3(2), 144-156.

Rašovská, I., Kubickova, M., \& Ryglová. K. (2021). Importance-performance analysis approach to destination management. Tourism Economics, 27(4), 777-794.

Reid, D.G., Mair, H., \& George, W. (2004). Community tourism planning: A self-assessment instrument. Annals of Tourism Research, 31(3), 623-639.

Ritchie, B.J.R., \& Crouch, G. (2000). The competitive destination: A sustainability perspective. Tourism Management, 21(1), 1-7. 
Ritchie, B.J.R., \& Crouch, G. (2003). The competitive destination. A sustainable tourism perspective. CABI Publishing.

Ruhanen, L., Weiler, B., Moyle, B.D., \& McLennan, C.L.J. (2015). Trends and patterns in sustainable tourism research: A 25-year bibliometric analysis. Journal of Sustainable Tourism, 23, 517-535.

Ryan, C. (2002). Equity, management, power sharing and sustainability - Issues of the new tourism. Tourism Management, $23,17-26$.

Sanagustin Fons, M.V., Mosene Fierro, J.A., \& Gomez y Patino, M. (2011). Rural tourism: A sustainable alternative. Applied Energy, 88, 551-557.

Schneider, D. (1978). The carrying capacity concept as a planning tool. American Planning Association.

Segui-Amortegui, L., Clemente-Almendros, J. A., Medina, R., \& Grueso Gala, M. (2019). Sustainability and competitiveness in the tourism industry and tourist destinations: A bibliometric study. Sustainability, 11(22), Article 6351.

Severiades, A. (2000). Establishing the social tourism carrying capacity for the tourist resorts of the east coast of the Republic of Cyprus. Tourism Management, 21, 147-156.

Sharma, R. (2016). Evaluating total carrying capacity of tourism using impact indicators. Global Journal of Environmental Science and Management, 2(2), 187-196.

Sharply, R. (2000). Tourism and sustainable development: Exploring the theoretical divide. Journal of Sustainable Tourism, $8(1), 1-19$.

Sharply, R. (2003). Rural tourism and sustainability - A critique. In D. Hall, L. Roberts, \& M. Mitchell (Eds.), New directions in rural tourism (pp. 38-53). Ashgate Publishing Limited.

Shi, T., Liu, X., \& Li, J. (2018). Market segmentation by travel motivations under a transforming economy: Evidence from the Monte Carlo of the Orient. Sustainability, 10(10), Article 3395.

Simmons, D.G. (1994). Community participation in tourism planning. Tourism Management, 15(2), 98-108.

Simón F.J., Narangajavan Y., \& Marqués D.P. (2004). Carrying capacity in the tourism industry: A case study of Hengistbury Head. Tourism Managment, 25, 275-283.

Simpson, K. (2001). Strategic planning and community involvement as contributors to sustainable tourism development. Current Issues in Tourism, 4(1), 3-41.

Smith, V. (1977). Hosts and guests: The anthropology of tourism. University of Philadelphia.

Stylianou-Lambert, T. (2011). Gazing from home: Cultural tourism and art museums. Annals of Tourism Research, $38(2), 403-421$.

Swarbrooke, J., \& Horner, S. (2004). Consumer behavior in tourism. Butterworth-Heinemann.

Tanguay, G.A., Rajaonson, J., \& Therrien, M.C. (2013). Sustainable tourism indicators: Selection criteria for policy implementation and scientific recognition. Journal of Sustainable Tourism, 21(6), 862-879.

Tosun, C. (2000). Limits to community participation in the tourism development process in developing countries. Tourism Management, 21(6), 613-633.

Tosun, C. (2001). Challenges of sustainable tourism development in the developing world: The case of Turkey. Tourism Management, 22, 289-303.

Trauer, B. (2006). Conceptualizing special interest tourism - Frameworks for analysis. Tourism Management, 27(2), 183-200.

United Nations Environmental Programme, Mediterranean Action Plan, Priority Actions Programme. (1997). Guidelines for carrying capacity assessment for tourism in Mediterranean coastal areas, priority action programme. Regional Activity Centre, Split.

United Nations World Tourism Organisation. (2019). Tourism Highlights 2018.

United Nations World Tourism Organization. (1981). Saturation of tourist destinations. Report of the Secretary General.

United Nations World Tourism Organization. (2001). The concept of sustainable tourism. http://www.world-tourism.org/ sustainable/concepts.htm

United Nations World Tourism Organization. (2004). Indicators of sustainable development for tourism destinations: A guidebook.

Van der Helm, R. (2009). The vision phenomenon: Towards a theoretical underpinning of visions of the future and the process of envisioning. Futures, 41, 96-104.

Vanhove, N. (2005). The economics of tourism destinations. Elsevier Butterworth - Heinemann.

Wehrmeyer, W., Clayton, A., \& Lum, K. (2002). Foresighting for development. Greener Management International, $37,24-37$.

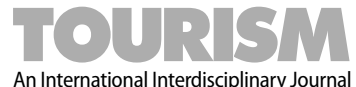

Zoran Klarić / Ivo Kunst

Pelješac Bridge Construction and Tourism Sustainability of the Peninsula, Croatia 
Wei, Y., Huang, C., Lam, P., Sha, Y., \& Feng, Y. (2015). Using urban-carrying capacity as a benchmark for sustainable urban development: An empirical study of Beijing. Sustainability, 7, 3244-3268.

Whitford, M.M., \& Ruhanen L.M. (2010). Australian indigenous tourism policy: Practical and sustainable policies? Journal of Sustainable Tourism, 18, 475-496.

World Commission on Environment and Development. (1987). Our common future. Oxford University Press.

World Economic Forum. (2019). The travel \& tourism competitiveness report 2019.

Ye, F., Park, J., Wang, F., \& Hu, X. (2020). Analysis of early warning spatial and temporal differences of tourism carrying capacity in China's island cities. Sustainability, 12, Article 1328.

Received: April 08, 2020

Revised: May 06, 2021

Accepted: May 21, 2021

Refereed Anonymously 